\title{
PEMETAAN PENYAKIT TUBERKULOSIS PARU DI WILAYAH KERJA PUSKESMAS KARANGAYU TAHUN 2016-2018
}

\author{
Arga Lukya Yan Pratama1', Fitria Wulandari ${ }^{*}$ \\ 1 Universitas Dian Nuswantoro \\ Email : Argalukya@gmail.com, Fitria.wulandari@dsn.dinus.ac.id*
}

Diterima : 27 April 2021 . Disetujui : 15 Juli 2021 . Dipublikasikan : 28 Juli 2021

\begin{abstract}
ABSTRAK
Berdasarkan survei awal di Puskesmas Karangayu, ditemukan kasus Tuberkulosis paru yang jumlahnya meningkat tiap tahunnya. Penelitian ini bertujuan untuk memetakan dan mendeskripsikan penyakit Tuberkulosis paru berdasarkan kelurahan, jenis kelamin, dan kelompok umur.

Penelitian ini adalah penelitian deskriptif, pengumpulan data dengan meninjau dokumen dan mencatat data yang dibutuhkan. Obyek penelitian adalah seluruh data pasien Tuberkulosis paru di Puskesmas Karangayu tahun 20162018.

Berdasarkan penelitian, mayoritas penderita penyakit Tuberkulosis paru berlokasi di Kelurahan Karangayu, laki-laki maupun perempuan mempunyai potensi yang sama untuk terkena TB paru, sebagian besar penderita termasuk dalam kelompok usia remaja dan dewasa. Sedangkan berdasarkan wilayah, Kelurahan Bojong Salaman yang jumlah penderitanya lebih merata, Kelurahan Salaman Mloyo baru pada tahun 2017 mulai ditemukannya penderita TB paru dan terakhir Kelurahan Cabean dengan jumlah penderita yang lebih sedikit.

Disimpulkan bahwa wilayah dengan kepadatan penduduk tinggi berisiko menyebabkan penularan, seluruh kelompok umur mempunyai kemungkinan terpapar penyakit khususnya dalam kelompok umur dewasa yang memiliki mobilitas tinggi.

Sebaiknya terus dilakukan program pengendalian dan pencegahan terhadap penyakit Tuberkulosis paru. Kata Kunci : Tuberkulosis Paru, Pemetaan, Rekam Medis
\end{abstract}

\section{ABSTRACT}

Based on a preliminary survey at the Karangayu Primary Health Center, the number of pulmonary tuberculosis cases is increasing every year. This study aims to map and describe pulmonary tuberculosis by kelurahan, gender, and age group

This study is a descriptive research, data collection by reviewing documents and records the data needed. The research object is all data of pulmonary tuberculosis patients in Karangayu Primary Health Center in 2016-2018.

Based on research, the majority of patients with pulmonary tuberculosis located in Karangayu village, men and women have the same potential to get pulmonary TB, most patients included in the adolescent and adult age groups. Whereas based on the region, Based on the kelurahan, The number of TB sufferers in Kelurahan Bojong Salaman was more evenly distributed, in Kelurahan Salaman Mloyo TB cases incidence were found in 2017 and the number of TB sufferers in Kelurahan Cabean was lower than the other kelurahan.

Areas with high population density are at risk of transmission. All age groups have the possibility of exposure to diseases, especially the adult age groups who have high mobility. Pulmonary tuberculosis disease control and prevention programs should continue.

Keywords : Tuberculosis of Lung, Mapping, Medical Record

\section{PENDAHULUAN}

Tuberkulosis paru merupakan peyakit menular yang disebabkan oleh infeksi bakteri Myocobacterium tuberculosis. Penyakit ini menyebar melalui droplet (partikel air yang keluar saat batuk atau bersin) orang yang telah terjangkit basil tuberkulosis. Sebagian besar kuman TB menyerang organ paru-paru, tetapi juga dapat mengenai organ tubuh lainnya. (Kementerian Kesehatan Republik Indonesia, 2017)

Tuberkulosis paru menjadi salah satu masalah kesehatan besar karena mudahnya penularan penyakit ini melewati udara. World Health Organization melaporkan bahwa angka insiden terjadinya kasus tuberkulosis di Indonesia berjumlah 391 per 100.000 
penduduk dan angka kematian sejumlah 42 per 100.000 penduduk(WHO, 2017)Jumlah kasus tertinggi dilaporkan terdapat di provinsi dengan jumlah penduduk yang besar yaitu Jawa Barat, Jawa Timur dan Jawa Tengah. Negara Indonesia tercatat sebagai peringkat ketiga di wilayah Asia Tenggara sebagai negara yang insiden kasus Tuberkulosis Parunya dikategorikan tinggi(Prevention, 2021) Dalam Profil Kesehatan Kota Semarang Tahun 2016 dan 2017,kasus Tuberkulosis paru tidak menduduki daftar 10 besar penyakit, namun grafik penemuan kasus Tuberkulosis paru meningkat dari tahun ke tahun (Dinas Kesehatan Kota Semarang, 2017)

Sistem informasi Geografis merupakan suatu sistem informasi yang dalam perancangannya digunakan untuk mengolah data geografis. Sistem ini dapat melakukan tangkapan untuk ditampilkan hingga dapat dilakukan manipulasi terhadap data geografis yang akan diolah(Indarto, 2013) Secara umum, pemanfaatan sistem informasi geografis dilakukan dengan tujuan untuk memudahkan dalam pengolahan data geografis yang menghasilkan suatu hasil analisa yang akurat dan berguna. Jika disangkutpautkan dalam segi kesehatan tentunya sangat banyak faedah yang didapatkan dari penerapan sistem informasi ini yang salah satunya dilakukan yaitu untuk menunjukkan keberadaan penyakit bahkan sampai pada penyebarannya(Edy irwansyah, 2016). Dalam penelitian kali ini di pilih aplikasi map info, Mapinfo Professional adalah aplikasi berbasis pc/laptop yang digunakan sebagai pembuatan tata letak geografis suatu wilayah atau permukaan bumi. Pada proses progres membuat peta, aplikasi ini dapat menggunakan data raster dan mebuat peta dengan metode tumpang tindih atau biasa disebut dengan overlay(wahana komputer, 2015)

Tabel 1 Kasus Tuberkulosis paru di Puskesmas Karangayu Berdasarkan Wilayah Kerja Tahun 2016
Berdasarkan survei awal yang telah dilakukan di Puskesmas Karangayu pada bulan Januari 2019, pada tahun 2016-2018 tercatat ditemukannya penyakit Tuberkulosis paru. Angka penemuan kasusnya meningkat dari tahun ke tahun yang menunjukkan penularan semakin meningkat.

Diketahui bahwa sistem pelaporan di Puskesmas Karangayu sebelum tahun 2018 belum menggunakan sistem pelaporan dalam bentuk pemetaan berbasis teknologi Sistem Informasi Geografis (SIG), pelaporan hanya sebatas pencatatan data terkait penyakit Tuberkulosis paru yang diinput dalam komputer untuk selanjutnya dilaporkan ke Dinas Kesehatan. Pada tahun 2018 pelaporan penyakit Tuberkulosis paru sudah menggunakan pemetaan penyakit berbasis Sistem Informasi Geografis (SIG) yang menggunakan aplikasi ArcGIS, namun masih menemukan kendala atau kekurangan yaitu pemetaan persebaran penyakit belum mencakup semua wilayah RW berdasarkan data yang ada. Dengan itu peneliti ingin melakukan pemetaan penyakit Tuberkulosis paru di wilayah kerja Puskesmas Karangayu pada tahun 2016-2018 dengan tujuan untuk menghasilkan berbagai informasi yang dapat dijadikan acuan dalam pengambilan keputusan serta untuk penyempurnaan hasil pemetaan yang sudah dilakukan pada tahun 2018.

\section{METODE PENELITIAN}

Jenis penelitian yang digunakan dalam penelitian ini adalah jenis penelitian deskriptif, yaitu penelitian yang bertujuan menjelaskan, menggambarkan objek penelitian berdasarkan keadaan nyata yang diamati di lapangan.

\section{HASIL DAN PEMBAHASAN}

Kasus Tuberkulosis paru di Puskesmas Karangayu Berdasarkan Wilayah Kerja Tahun 2016-2018

\begin{tabular}{|c|c|c|c|}
\hline No & Kelurahan & Jumlah & $\%$ \\
\hline 1. & Karangayu & 5 & 45 \\
\hline 2. & Salaman Mloyo & 0 & 0 \\
\hline 3. & Cabean & 0 & 0 \\
\hline \multirow[t]{2}{*}{4.} & Bojong Salaman & 6 & 55 \\
\hline & Total & 11 & 100 \\
\hline
\end{tabular}

Sumber : Data pasien kasus Tuberkulosis paru 
Tabel 2 Kasus Tuberkulosis paru di Puskesmas Karangayu Berdasarkan Wilayah Kerja Tahun 2017

\begin{tabular}{clccc}
\hline No & & Kelurahan & Jumlah & $\%$ \\
\hline 1. & Karangayu & 4 & 29 \\
2. & Salaman Mloyo & 4 & 29 \\
3. & Cabean & 1 & 7 \\
4. & Bojong Salaman & 5 & 36 \\
\hline & Total & 14 & 100
\end{tabular}

Sumber : Data pasien kasus Tuberkulosis paru

Tabel 3 Kasus Tuberkulosis paru di Puskesmas Karangayu Berdasarkan Wilayah Kerja Tahun 2018

\begin{tabular}{clccc}
\hline No & & Kelurahan & Jumlah & $\%$ \\
\hline 1. & Karangayu & 10 & 56 \\
2. & Salaman Mloyo & 5 & 28 \\
3. & Cabean & 1 & 6 \\
4. & Bojong Salaman & 2 & 11 \\
\hline & Total & 18 & 100 \\
\hline
\end{tabular}

Sumber : Data pasien kasus Tuberkulosis paru

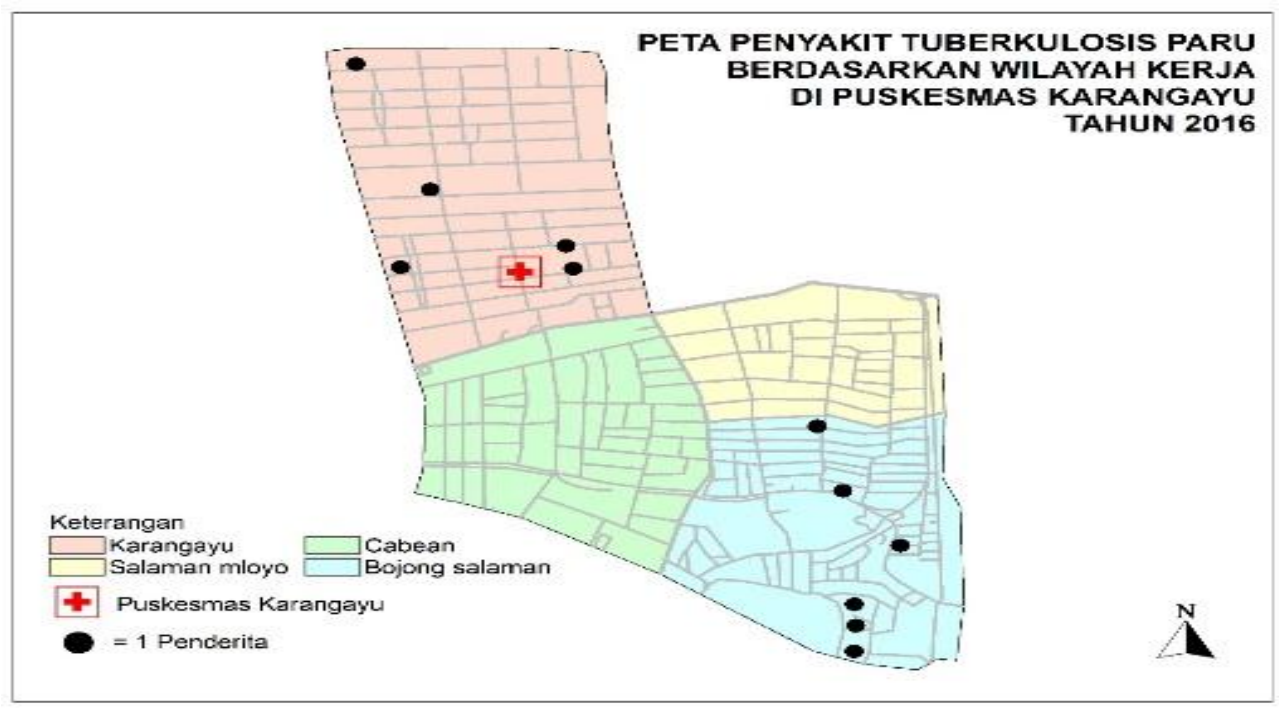

Gambar 1 Peta Penyakit Tuberkulosis Paru Berdasarkan Wilayah Kerja di Puskesmas Karangayu Tahun 2016

Berdasarkan Gambar 1 pada tahun 2016

Kelurahan Bojong Salaman merupakan kelurahan yang kasus Tuberkulosis parunya tertinggi diikuti Kelurahan Karangayu, sedangkan Kelurahan
Salaman Mloyo dan Kelurahan Cabean merupakan kelurahan yang kasus Tuberkulosis parunya terendah 


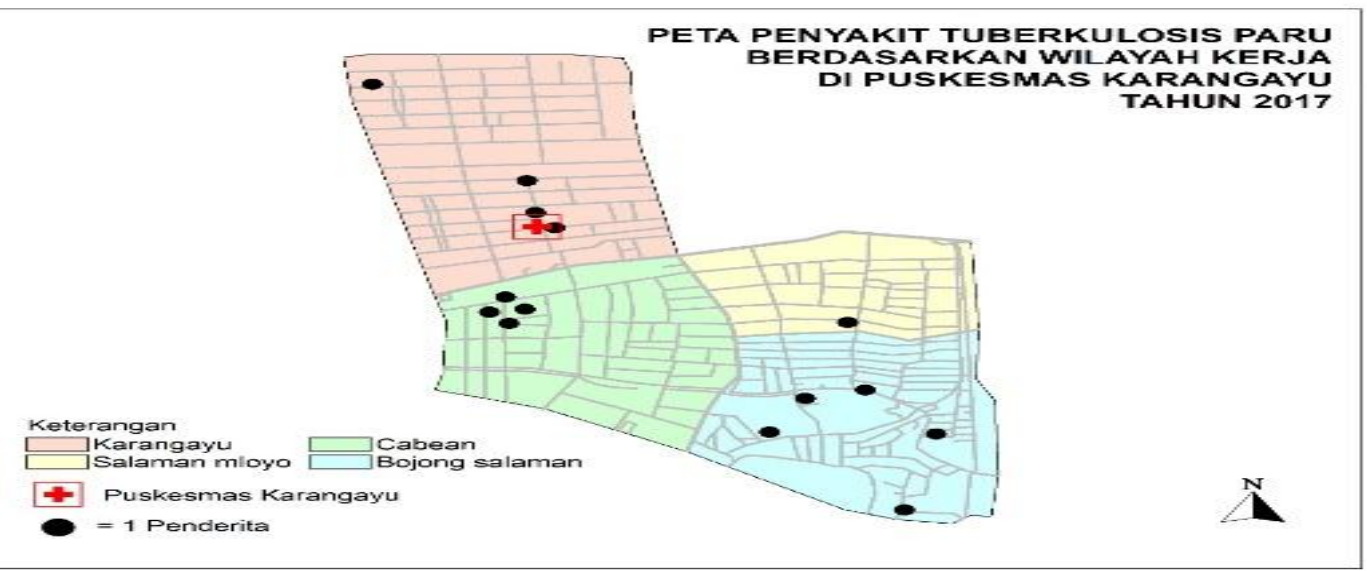

Gambar 2 Peta Penyakit Tuberkulosis Paru Berdasarkan Wilayah Kerja di Puskesmas Karangayu Tahun 2017

Berdasarkan Gambar 2 pada tahun 2017 Kelurahan Bojong Salaman merupakan kelurahan yang kasus Tuberkulosis parunya tertinggi, diikuti Kelurahan Karangayu dan Kelurahan Salaman Mloyo dengan jumlah penderita sama banyak, sedangkan Kelurahan Cabean merupakan kelurahan yang kasus Tuberkulosis parunya terendah.

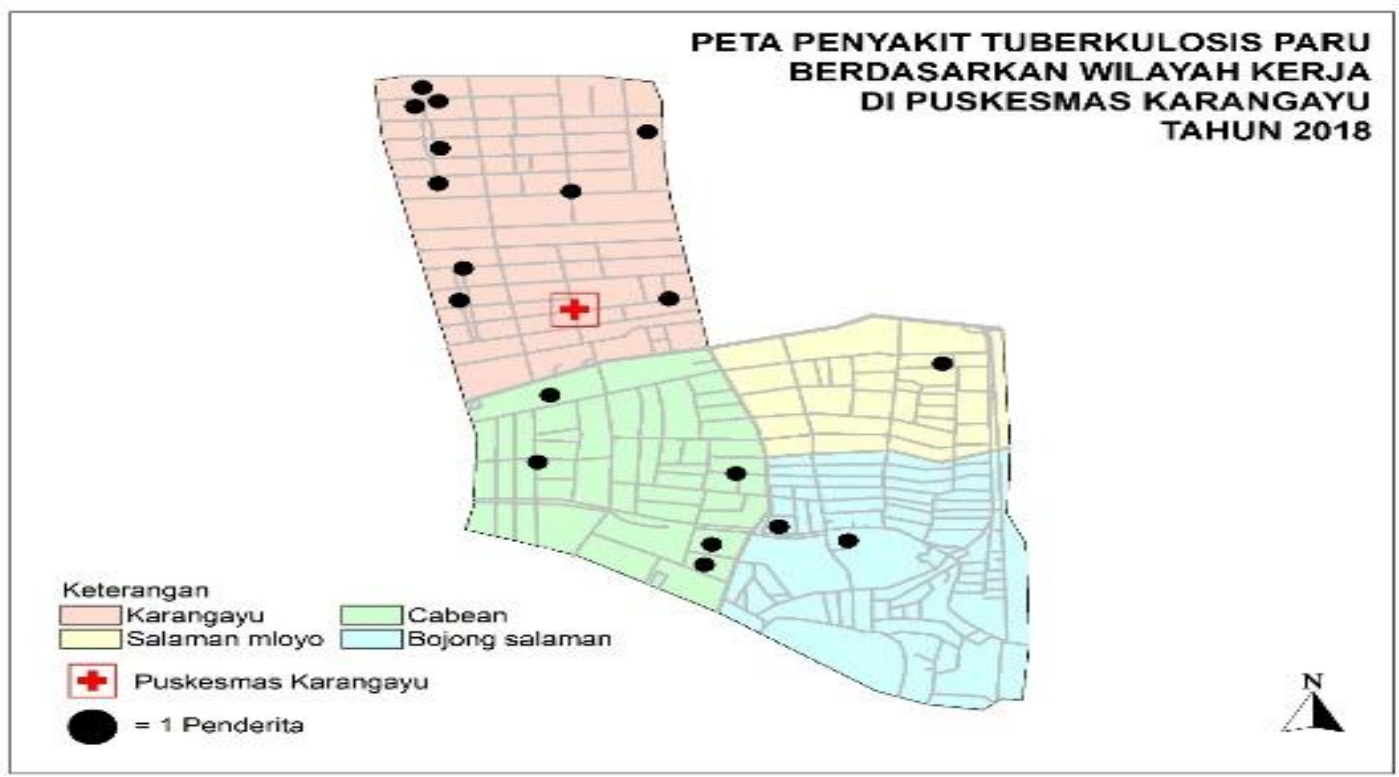

Gambar 3 Peta Penyakit Tuberkulosis Paru Berdasarkan Wilayah Kerja di Puskesmas Karangayu Tahun 2018

Berdasarkan Gambar 3 pada tahun 2018 Kelurahan Karangayu merupakan kelurahan yang kasus Tuberkulosis parunya tertinggi, diikuti Kelurahan Salaman Mloyo dan Kelurahan Bojong
Salaman dan terakhir Kelurahan Cabean merupakan kelurahan yang kasus Tuberkulosis parunyaterendah

1. Kasus Tuberkulosis paru di Puskesmas Karangayu Berdasarkan Jenis Kelamin Tahun 2016-2018 Tabel 4 Kasus Tuberkulosis paru di Puskesmas Karangayu Berdasarkan Jenis Kelamin Tahun 2016

\begin{tabular}{cccccc}
\hline & & \multicolumn{5}{c}{ Jenis Kelamin } \\
\cline { 3 - 6 } No & Kelurahan & Laki-laki & $\%$ & Perempuan & $\%$ \\
\hline 1. & Karangayu & 3 & 27,3 & 2 & 18,2 \\
2. & Salaman Mloyo & 0 & 0 & 0 & 0 \\
\hline
\end{tabular}

Pemetaan Penyakit Tuberkulosis Paru Di Wilayah Kerja ...

(Arga Lukya Yan Pratama, Fitria Wulandari) 


\begin{tabular}{cccccc}
\hline \multirow{2}{*}{ No } & \multirow{2}{*}{ Kelurahan } & \multicolumn{4}{c}{ Jenis Kelamin } \\
\cline { 3 - 6 } & Bojong Salaman & 2 & $\%$ & Perempuan & $\%$ \\
\hline 4. & Total & 5 & 48,2 & 4 & 36,4 \\
\hline & Baki-laki & & 6 & 54,5 \\
\hline
\end{tabular}

Sumber : Data pasien kasus Tuberkulosis paru

Tabel 5 Kasus Tuberkulosis paru di Puskesmas Karangayu Berdasarkan Jenis Kelamin Tahun 2017

\begin{tabular}{cccccc}
\hline \multirow{2}{*}{ No } & \multirow{2}{*}{ Kelurahan } & \multicolumn{4}{c}{ Jenis Kelamin } \\
\cline { 3 - 6 } & & Laki-laki & $\%$ & Perempuan & $\%$ \\
\hline 1. & Karangayu & 1 & 7 & 3 & 21 \\
2. & Salaman Mloyo & 2 & 14 & 2 & 14 \\
3. & Cabean & 1 & 7 & 0 & 0 \\
4. & Bojong Salaman & 3 & 21 & 2 & 14 \\
\hline & Total & 7 & 50 & 7 & 50 \\
\hline
\end{tabular}

Sumber : Data pasien kasus Tuberkulosis paru

Tabel 6 Kasus Tuberkulosis paru di Puskesmas Karangayu Berdasarkan Jenis Kelamin Tahun 2018

\begin{tabular}{cccccc}
\hline \multirow{2}{*}{ No } & \multirow{2}{*}{ Kelurahan } & \multicolumn{5}{c}{ Jenis Kelamin } \\
\cline { 3 - 6 } & & Laki-laki & $\%$ & Perempuan & $\%$ \\
\hline 1. & Karangayu & 4 & 22 & 6 & 33 \\
2. & Salaman Mloyo & 3 & 17 & 2 & 11 \\
3. & Cabean & 1 & 6 & 0 & 0 \\
4. & Bojong Salaman & 1 & 6 & 1 & 6 \\
\hline & Total & 9 & 50 & 9 & 50 \\
\hline
\end{tabular}

Sumber : Data pasien kasus Tuberkulosis paru

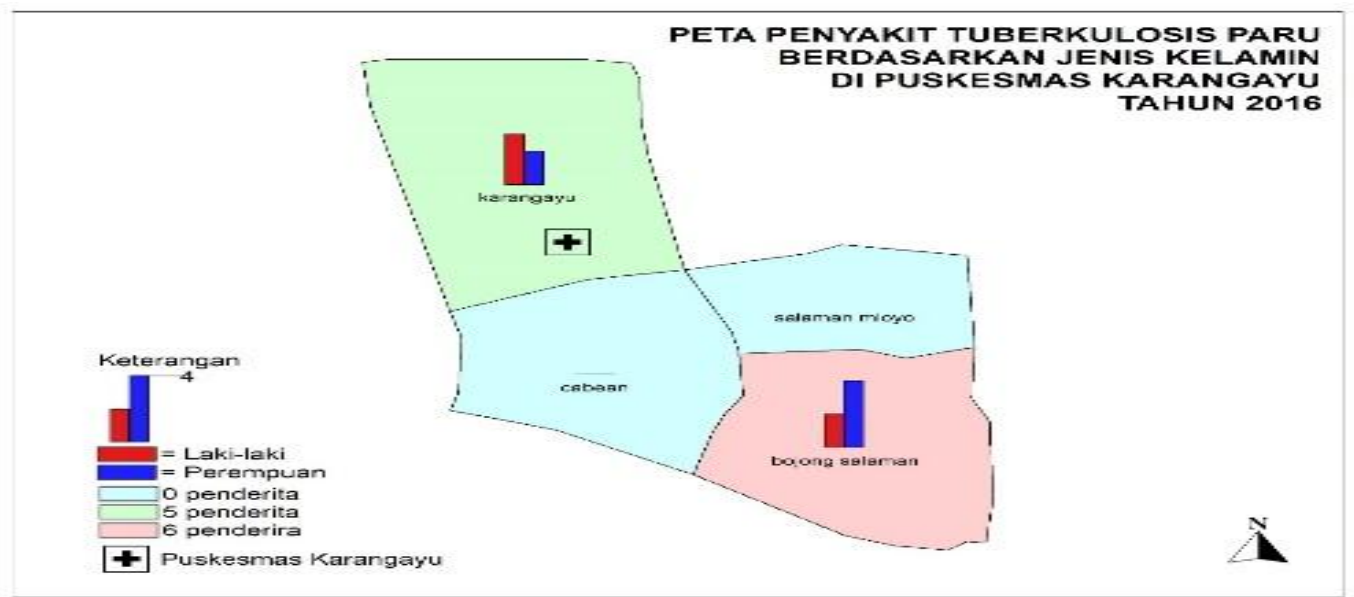

Gambar 4 Peta Penyakit Tuberkulosis Paru Berdasarkan Jenis Kelamin di Puskesmas Karangayu Tahun 2016

Berdasarkan Gambar 4 pada tahun 2016 hanya 2 kelurahan dalam wilayah kerja Puskesmas Karangayu yang terdapat penderita TB paru. Grafik penderita perempuan menunjukkan angka yang lebih tinggi dari pada penderita laki-laki di Kelurahan Bojong Salaman. 


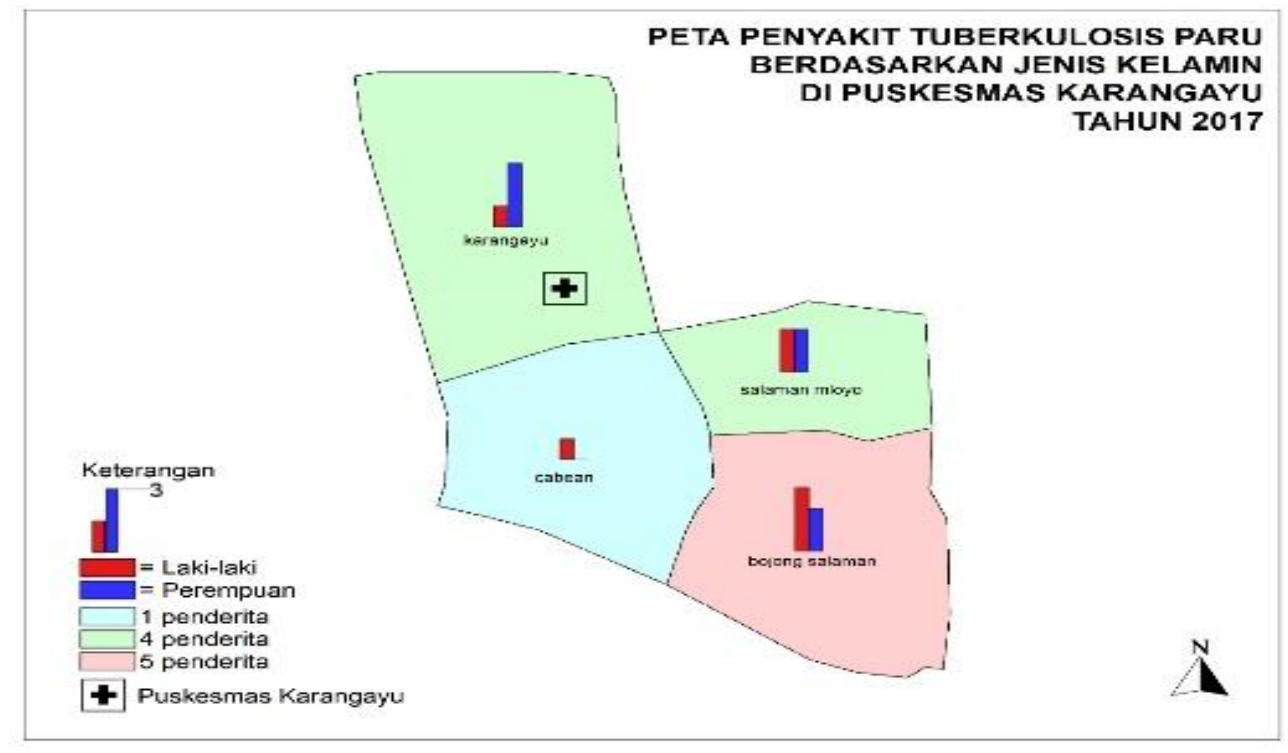

Gambar 5 Peta Penyakit Tuberkulosis Paru Berdasarkan Jenis Kelamin di Puskesmas Karangayu Tahun 2017

Berdasarkan Gambar 5 pada tahun 2017 diketahui penderita laki-laki dan perempuan sangat tidak stabil disetiap kelurahannya. Di Kelurahan Karangayu terdapat 1 penderita laki-laki dan 7 perempuan. Di Kelurahan Salaman Mloyo terdapat 2 penderita laki-laki dan 2 perempuan. Di Kelurahan Cabean terdapat 1 penderita laki-laki dan 0 perempuan. Di Kelurahan Bojong Salaman terdapat 3 penderita laki-laki dan 2 perempuan.

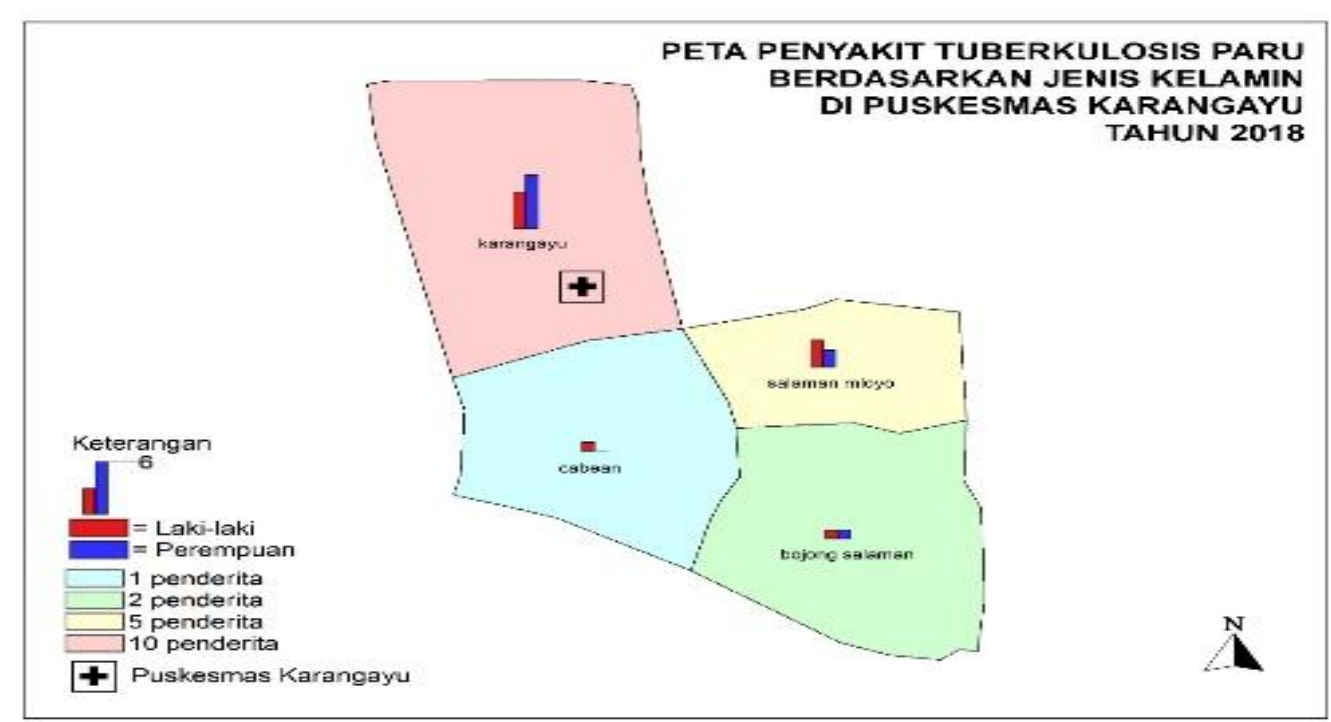

Gambar 6 Peta Penyakit Tuberkulosis Paru Berdasarkan Jenis Kelamin di Puskesmas Karangayu Tahun 2018

Berdasarkan Gambar 6 pada tahun 2018 diketahui penderita laki-laki dan perempuan sangat tidak stabil disetiap kelurahannya. Di Kelurahan Karangayu terdapat 4 penderita laki-laki dan 6 perempuan. Di Kelurahan Salaman mloyo terdapat 3 penderita laki- laki dan 2 perempuan. DiKelurahan Cabean terdapat 1 penderita laki-laki dan 0 perempuan. Di Kelurahan Bojong salaman terdapat 1 penderita laki-laki dan 1 perempuan. 
3. Kasus Tuberkulosis paru di Puskesmas Karangayu Berdasarkan Kelompok Umur Tahun 2016

Tabel 7

Kasus Tuberkulosis paru di Puskesmas Karangayu Berdasarkan Kelompok Umur Tahun 2016

\begin{tabular}{|c|c|c|c|c|c|c|c|c|c|}
\hline \multirow[t]{2}{*}{ No } & \multirow{2}{*}{ Kelurahan } & & & \multicolumn{6}{|c|}{ Kelompok Umur } \\
\hline & & $<13$ & $\%$ & $14-25$ & $\%$ & $26-55$ & $\%$ & $>56$ & $\%$ \\
\hline 1. & Karangayu & 0 & 0 & 0 & 0 & 5 & 45 & 0 & 0 \\
\hline 2. & Salaman Mloyo & 0 & 0 & 0 & 0 & 0 & 0 & 0 & 0 \\
\hline 3. & Cabean & 0 & 0 & 0 & 0 & 0 & 0 & 0 & 0 \\
\hline 4. & Bojong Salaman & 0 & 0 & 2 & 18 & 4 & 36 & 0 & 0 \\
\hline & Total & 0 & 0 & 2 & 18 & 9 & 82 & 0 & 0 \\
\hline
\end{tabular}

Sumber : Data pasien kasus Tuberkulosis paru

Tabel 8

Kasus Tuberkulosis paru di Puskesmas Karangayu Berdasarkan Kelompok Umur Tahun 2017

\begin{tabular}{cccccccccc}
\hline \multirow{2}{*}{ No } & Kelurahan & \multicolumn{1}{c}{ Kelompok Umur } \\
\cline { 3 - 10 } & & $<13$ & $\%$ & $14-25$ & $\%$ & $26-55$ & $\%$ & $>56$ & $\%$ \\
\hline 1. & Karangayu & 0 & 0 & 1 & 7 & 2 & 14 & 1 & 7 \\
2. & Salaman Mloyo & 0 & 0 & 0 & 0 & 4 & 29 & 0 & 0 \\
3. & Cabean & 0 & 0 & 0 & 0 & 0 & 0 & 1 & 7 \\
4. & Bojong Salaman & 1 & 7 & 1 & 7 & 2 & 14 & 1 & 7 \\
\hline & Total & 1 & 7 & 2 & 14 & 8 & 57 & 3 & 21 \\
\hline
\end{tabular}

Sumber : Data pasien kasus Tuberkulosis paru

Tabel 9

Kasus Tuberkulosis paru di Puskesmas Karangayu Berdasarkan Kelompok Umur Tahun 2018

\begin{tabular}{cccccccccc}
\hline & & \multicolumn{7}{c}{ Kelompok Umur } \\
\cline { 3 - 8 } No & Kelurahan & $<13$ & $\%$ & $14-25$ & $\%$ & $26-55$ & $\%$ & $>56$ & $\%$ \\
\hline 1. & Karangayu & 2 & 11 & 3 & 17 & 4 & 22 & 1 & 6 \\
2. & Salaman Mloyo & 0 & 0 & 0 & 0 & 4 & 22 & 1 & 6 \\
3. & Cabean & 0 & 0 & 0 & 0 & 1 & 6 & 0 & 0 \\
4. & Bojong Salaman & 0 & 0 & 1 & 6 & 1 & 6 & 0 & 0 \\
\hline & Total & 2 & 11 & 4 & 22 & 10 & 56 & 2 & 11 \\
\hline
\end{tabular}

Sumber : Data pasien kasus Tuberkulosis paru

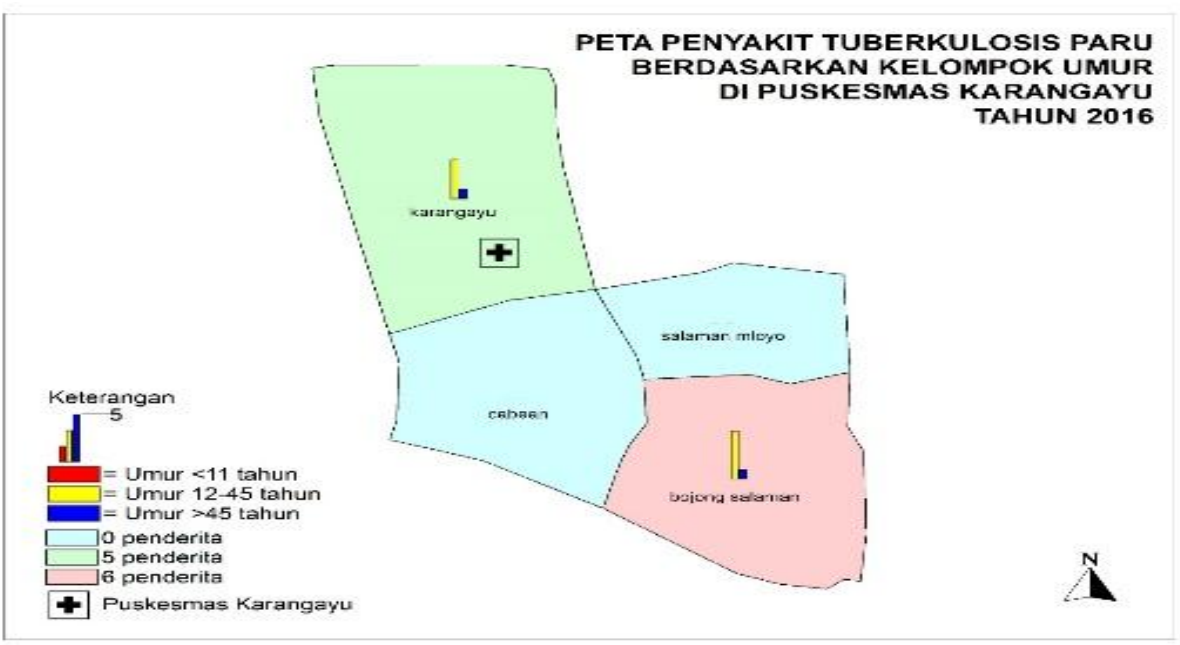

Gambar 7 Peta Penyakit Tuberkulosis Paru Berdasarkan Kelompok Umur di Puskesmas Karangayu Tahun 2016 
Berdasarkan Gambar 7 pada tahun 2016 hanya 2 kelurahan dalam wilayah kerja yang terdapat penderita penyakit yaitu dalam kelompok umur 1245 tahun dan $>45$ tahun. Diketahui penderita dalam kelompok umur 12-45 tahun menjadi penderita terbanyak diikuti penderita kelompok umur $>45$ tahun dan kelompok umur $<11$ tahun yang tidak terdapat penderita.

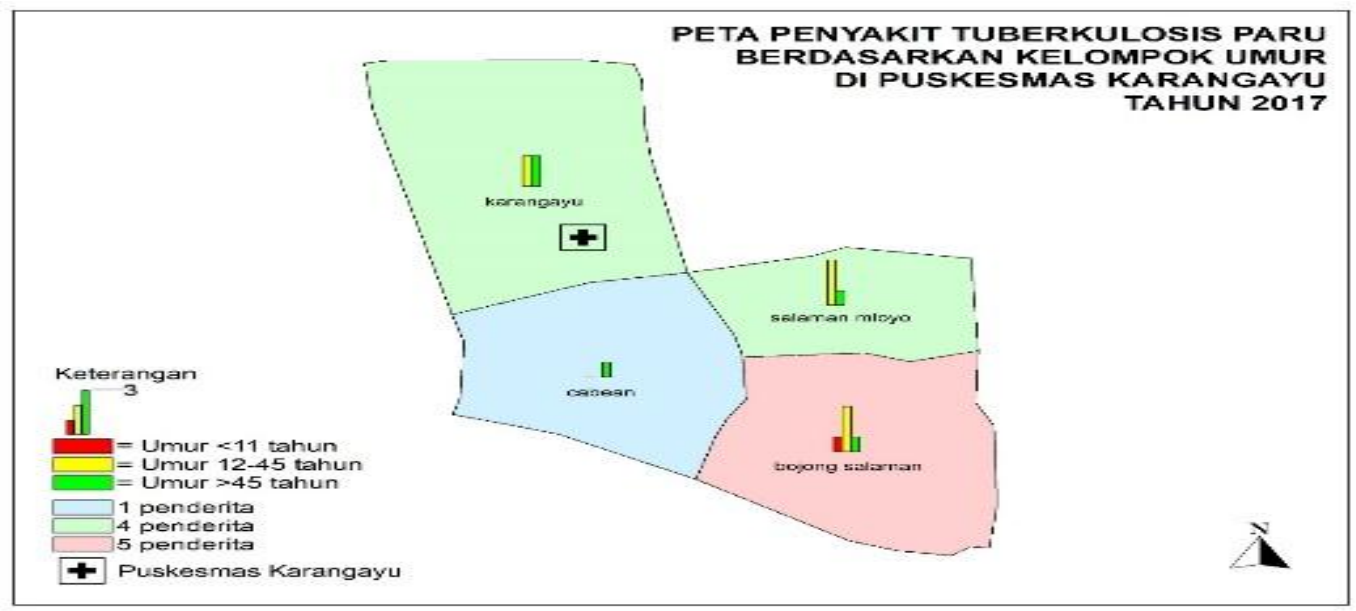

Gambar 8 Peta Penyakit Tuberkulosis Paru Berdasarkan Kelompok Umur di Puskesmas Karangayu Tahun 2017

Berdasarkan Gambar 8 pada tahun 2017 seluruh kelurahan dalam wilayah kerja yang terdapat penderita penyakit yaitu pada seluruh kelompok umur. Diketahui penderita dalam kelompok umur 12-45 tahun menjadi penderita terbanyak diikuti penderita kelompok umur $>45$ tahun dan mulai ditemukannya penderita penyakit pada kelompok umur $<11$ tahun.

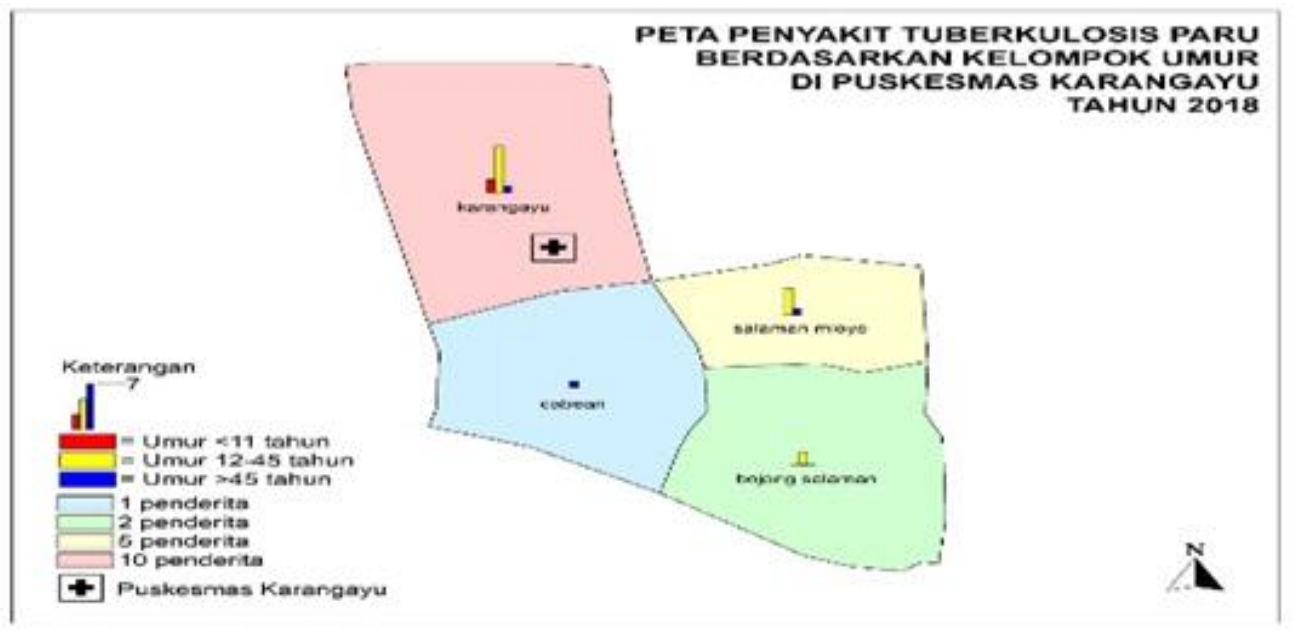

Gambar 9 Peta Penyakit Tuberkulosis Paru Berdasarkan Kelompok Umur di Puskesmas Karangayu Tahun 2018

Berdasarkan Tabel 9 pada tahun 2019 seluruh kelompok umur terdapat penderita penyakit kasus Tuberkulosis paru. Diketahui penderita dalam kelompok umur 12-45 tahun menjadi penderita terbanyak diikuti penderita kelompok umur $>45$ tahun dan kelompok umur $<11$ tahun dengan jumlah yang meningkat dari tahun sebelumnya.
Kasus Tuberkulosis paru di Puskesmas Karangayu Berdasarkan Wilayah Kerja Tahun 2016 - 2018.

Dari hasil penelitian mengenai pemetaan kasus Tuberkulosis paru di Puskesmas Karangayu berdasarkan wilayah kerja tahun 2016 - 2018, total terdapat 43 kasus dari empat wilayah kerja yang ditemukan kasus Tuberkulosis paru. Jumlah yang ditemukan semakin naik dalam tiga tahun terakhir 
yaitu pada tahun 2016 berjumlah 11 kasus, tahun 2017 berjumlah 14 kasus dan tahun 2018 berjumlah 18 kasus.

Dalam empat kelurahan, selama tiga tahun Kelurahan Karangayu dan Bojong salaman cenderung menjadi wilayah mayoritas dibandingkan dengan kelurahan lainnya. Jumlah penderita di Kelurahan Karangayu selama 3 tahun mengalami naik turun sedangkan Kelurahan bojong salaman terus mengalami penurunan. Pada Kelurahan cabean dan salaman mloyo mulai ditemukannya penderita TB paru di tahun 2017 yang sebelumnya pada tahun 2016 tidak ditemukannya penderita. Angka temuan penderita di Kelurahan cabean pada tahun 2017-2018 tidak menunjukan peningkatan atau penurunan yang diketahui sama-sama berjumlah 1 penderita. Namun di Kelurahan Salaman mloyo diketahui pada tahun 2016 tidak ditemukannya penderita TB paru kemudian pada tahun 2017 mulai ditemukan dengan jumlah sebesar 4 penderita yang pada tahun berikutnya meningkat menjadi 5 penderita.

Kepadatan penduduk merupakan salah satu faktor penyebab mudahnya penyebaran penyakit Tuberkulosis paru, semakin banyak penduduk dalam suatu wilayah maka tingkat penularannya semakin tinggi. Diketahui kelurahan dalam wilayah kerja Puskesmas Karangayu yang selama 3 tahun mengalami peningkatan adalah Kelurahan Karangayu dan Salaman mloyo. Angka kepadatan penduduk di Kelurahan Karangayu pada tahun 2016 dan 2017 berjumlah $13.304 \mathrm{~km} 2$ dan meningkat pada tahun 2018 menjadi $13.721 \mathrm{~km} 2$. Begitu juga di Kelurahan Salaman mloyo yang pada tahun 2016 dan 2017 memiliki angka kepadatan penduduk berjumlah 6.122 km2 dan mengalami kenaikan pada tahun 2018 menjadi $6.312 \mathrm{~km} 2$. Penelitian ini sejalan dengan penelitian yang dilakukan oleh Yulinur Firdaus yang menunjukkan bahwa penyebaran kasus Tuberkulosis paru di Kota Surabaya terkonsentrasi pada wilayah dengan kepadatan penduduk yang tinggi(Firdaus $Y$, 2016) Penelitian ini sejalan dengan penelitian yang dilakukan oleh Karolina, A yang menyebutkan bahwa sebaran penderita TB Paru menumpuk pada daerah yang merupakan indikator adanya kepadatan penduduk yang tinggi.(Karolina A, 2015) Penelitian ini sejalan dengan penelitian yang dilakukan oleh Arum Siwiendrayanti yang menunjukkanterdapat hubungan yang signifikan antara kepadatan penduduk dengan jumlah kasus TB paru(Siwiendrayati, 2018), penelitian lain yang menunjukkan hasil yang sama dengan yang di lakukan oleh peneliti adalah peneltian yang dilakukan oleh bambang rusmanto, mengenai analisis spasial sebaran kasus tuberkulosis paru ditinjau dari lingkungan fisik di dalam dan diluar rumahdi kabupaten pekalongan, pada tahun 2010, yang menyebutkan bahwa terdapat hubungan yang significant anata suhu udara didalam dan diluar rumah,, jenis lantai, dan kontak penderita yang terbukti berhubungan dengan kejadian tuberkulosis paru (dotulong, 2015), selain itu menurut penelitian Edza W, yang dilakukan pada penderita tuberkulosis di Suarabaya mendapatkan hasil bahwa, selain kepadatan penduduk tingkat sosial ekonomi juga mempengaruhi terjadinya kasus tuberkulosis ${ }^{(8)}$.

\section{Kasus Tuberkulosis paru di Puskesmas Karangayu} Berdasarkan Jenis Kelamin Tahun 2016 - 2018

Dari hasil penelitian mengenai pemetaan kasus Tuberkulosis paru di Puskesmas Karangayu berdasarkan jenis kelamin tahun 2016 - 2018, diketahui baik laki-laki maupun perempuan memiliki tingkat kecenderungan tertular penyakit Tuberkulosis paru yang hampir sama. Pada tahun 2016 didapatkan bahwa jenis kelamin perempuan menjadi mayoritas penderita yang dapat dilihat dari tinggi grafik di keseluruhan wilayah kerja. Pada tahun 2017 baik lakilaki dan perempuan menunjukkan grafik jumlah penderita yang sama, namun jenis kelamin laki-laki menjadi mayorits penderita karena jumlah persebaran yang lebih merata yaitu terdapat penderita di setiap kelurahan wilayah kerjanya. Pada tahun 2018 baik laki-laki dan perempuan menunjukkan grafik jumlah penderita yang sama, namun penderita laki-laki menjadi mayorits karena jumlah persebaran yang lebih merata yaitu terdapat penderita di setiap kelurahan wilayah kerjanya.

Didapatkan bahwa pada tahun 2016-2018 baik penderita laki-laki dan penderita perempuan jumlahnya sama, namun persebaran kasus pada penderita lakilaki lebih merata di setiap kelurahannya yang artinya penderita laki-laki memiliki peluang lebih besar untuk tertular penyakit Tuberkulosis karena laki-laki memiliki mobilitas yang lebih tinggi dari perempuan serta dipengaruhi oleh kebiasaan merokok atau kontak dengan udara lingkungan tidak sehat karena pekerjaan. Penelitian ini sejalan dengan penelitian yang dilakukan oleh Jendra F.J Dotulong, yang menunjukkan adanya hubungan antara jenis kelamin 
dengan temuan kasus Tuberkulosis paru. (bambang riswanto, 2012), serta penelitian dari M. choirurur rozikin, dan andri permana wicaksono, yang dilakukan pada tahun 2016 mengenai analisis statistik dan pemetaan kasus tuberkulosis anak dan tuberkulosis dewasa di kabupaten jember, dimana penelitian ini mendapatkan hasil bahwa penderita Tuberkulosis pada laki-laki dewasa lebih banyak/lebih tinggi di bandingkan dengan penderita tuberkulosis pada perempuan dewasa maupun anak-anak(Choirur rozikin, $M$, Permana Wicaksono, A, 2018) Penelitian ini tidak sejalan dengan penelitian yang menunjukkan bahwa perbandingan penderita laki-laki dan perempuan adalah 1:2 yang artinya perempuan lebih potensi tertular lebih tinggi(Budi I, 2018)

\section{Kasus Tuberkulosis paru di Puskesmas Karangayu}

Berdasarkan Kelompok Umur Tahun 2016 - 2018

Dari hasil penelitian mengenai pemetaan kasus Tuberkulosis paru di Puskesmas Karangayu berdasarkan kelompok umur tahun 2016 - 2018, didapatkan bahwa penyakit Tuberkulosis paru dapat menyerang seluruh kelompok umur penderita baik anak-anak (<13 tahun), remaja (14-25 tahun), dewasa (26-55 tahun) dan lansia (>56 tahun).

Pada kelompok usia anak-anak tidak ditemukannya kasus di tahun 2016 dan mulai ditemukan pada tahun 2017 dan mengalami kenaikan pada tahun 2018 yaitu dari 1 penderita menjadi 2 penderita. Sedangkan kelompok usia remaja berdasarkan data yang telah diolah, dalam kasus selama 3 tahun tetap berada dalam jumlah yanag sama yaitu 2 penderita setiap tahunnya.

Dalam 3 tahun terakhir, penderita TB paru yang menjadi mayoritas penderita adalah kelompok usia dewasa yang setiap tahunnya mengalami naik turun dengan jumlah yang tidak jauh berbeda. Sedangakan untuk kelompok usia lansia yang pada tahun 2016 tidak ditemukan kasus TB paru, mulai ditemukan pada tahun 2017 dan mengalami penurunan pada tahun berikutnya dari 3 penderita menjadi 2 penderita.

Kelompok umur dewasa adalah kelompok usia yang memiliki mobilitas yang sangat tinggi sehingga kemungkinan terpapar dengan kuman mycobacterium tuberculocis lebih tinggi. Penelitian ini sejalan dengan penelitian yang dilakukan oleh Jendra F.J Dotulong yang menyatakan bahwa ada hubungan antara kelompok umur dengan temuan kasus Tuberkulosis paru. ${ }^{[8]}$

\section{SIMPULAN DAN SARAN}

Kasus Tuberkulosis paru mengalami kenaikan di setiap tahunnya yaitu pada tahun 2016-2017 mengalami kenaikan dari 11 penderita menjadi 14 penderita dan pada tahun 2017-2018 mengalami kenaikan lagi dari 14 penderita menjadi 18 penderita.Potensi terjadinya penularan di setiap kelurahan tetap harus diwaspadai karena adanya faktor kepadatan penduduk yang meningkat setiap tahunnya. Laki laki mempunyai potensi lebih besar menderita Tuberkulosis paru dibandingkan dnegan perempuan dan anak-anak. Penggunaan pemetaan dapat mempermudah pemantauan kejadian tuberkulosis yang terjadi pada satu wilayah kerja puskesmas.

\section{DAFTAR PUSTAKA}

bambang riswanto (2012) 'Analisis sebaran sebaran kasus tuberkulosis paru ditinjau dari faktor lingkungan fisik dalam dan luar rumah di kabupaten pekalongan', Jurnal Kesehatan Lingkungan Indonesia.

Budi I (2018) 'Analisis faktor Risiko Kejadian Tuberkulosis bagi masyarakat di daerah kumuh kota palembang', Jurnal Kesehatan Lingkungan Indonesia, 17(2), pp. 87-94.

Choirur rozikin, M, Permana Wicaksono, A (2018) 'analisis statistik dan pemetaan kasus tuberkulosis anak dan dewasa di kabupaten jember', Jurnal Kesehatan, 6(1).

Dinas Kesehatan Kota Semarang (2017) Profil Kesehatan Kota Semarang tahun 2017. Semarang.

dotulong, j (2015) 'Hubungan faktor risiko umur, jenis kelamin, dan kepadatanpenduduk hunian dengan kejadian penyakit tuberkulosis paru di desa wori', Jurnal kedokteran komunitas dan tropik, 3(2).

Edy irwansyah (2016) Sistem Informasi Geografis, prinsip dasar dan pengembangan. Yogyakarta.

Firdaus Y (2016) 'pemetaan penyakit tuberkulosis di kota surabaya tahun 2014', Jurnal ilmiah keperawatan, 2, pp. 42-50.

Indarto (2013) SISTEM INFORMASI GEOGRAFIS. Graha ilmu.

Karolina A (2015) 'pemetaan kasus tuberkulosis paru fi kecamatan tuminting tahun 2013', Jurnal kedokteran komunitas dan tropik, 3(1). 
Kementerian Kesehatan Republik Indonesia (2017) Profil Kesehatan Indonesia 2017.

Prevention, C. for D. C. and (2021) 'Core Curriculum on Tuberculosis: What the Clinician Should Know', Centers for Disease Control and Prevention National Center for HIV/AIDS, Viral Hepatitis, STD, and TB Prevention Division of Tuberculosis Elimination, pp. 1-320. Available at: http://www.cdc.gov/tb.
Siwiendrayati, A. (2018) 'Analisis spasial dan temporal persebaran kasus TB paru BTA (+) di kabupaten batang', Jurnal Kesehatan Lingkungan Indonesia.

wahana komputer (2015) Sistem informasi Geografis dengan map info. Elex media komputindo.

WHO (2017) World Health Organization Global Report2017. 